ks. Wojciech Medwid ${ }^{1}$

Uniwersytet Papieski Jana Pawła II w Krakowie

\title{
Przekroczyć próg jednoczesnej sprawiedliwości i grzeszności wierzącego
}

W podpisanej w 1999 roku przez Kościół katolicki i Światową Federację Luterańską Wspólnej deklaracji został osiągnięty zróżnicowany konsensus dotyczący iustificatio. Bez wątpienia należy uznać znaczenie i doniosłość tego faktu. Owa zgodność odnosi się jedynie do podstawowych prawd nauki o usprawiedliwieniu, ponieważ nie wszystkie aspekty tego zagadnienia uzyskały pełną zgodność partnerów dialogu. To spowodowało wyłonienie się dopuszczalnych różnic w ramach obu wspólnot eklezjalnych. Można powiedzieć, że różnice porozumienia wytyczyły jego granice, będące jednocześnie inspiracją do różnych sposobów dochodzenia do prawdy, jak i próbą innego ujęcia zagadnienia. Istniejące zaś rozbieżności między katolikami a luteranami można sprowadzić do trzech szczególnych różnic: formuła simul iustus et peccator, współpraca z łaską i funkcje nauki o usprawiedliwieniu ${ }^{2}$. Najbardziej sporną i kontrowersyjną rozbieżnością w dialogu teologicznym katolików i protestantów uwa-

1 Wojciech Medwid, doktor; ksiądz diecezji bielsko-żywieckiej Kościoła rzymskokatolickiego, absolwent Wydziału Teologicznego Uniwersytetu Papieskiego Jana Pawła II w Krakowie, obecnie pracuje w parafii św. Klemensa w Ustroniu.

2 Por. W. Medwid, Usprawiedliwienie w dialogu katolicko-luterańskim, Kraków 2010, s. 282 299; A. Napiórkowski, Bogactwo łaski a nędza grzesznika, Kraków 2000, s. 314-315; H. Wagner, Dogmatyka, przekł. J. Zychowicz, Kraków 2007, s. 239-240. 
ża się sformułowanie, że usprawiedliwiony jest jednocześnie sprawiedliwy i grzeszny. Zagadnienie to zaczęto w teologii określać mianem simul iustus et peccator. Bez wątpienia może ono być postrzegane jako rdzeń ekumenicznej debaty o usprawiedliwieniu, bo do niego powracają wszystkie inne kontrowersyjne kwestie dotyczące iustificatio. Jaki jest związek między tym, co święte, i tym, co grzeszne? Czy katolickie odrzucanie powyższej zasady jest słuszne? Czy jest racja w tym, że jednoczesny charakter bycia usprawiedliwionym i grzesznikiem nie bierze na poważnie wydarzenia usprawiedliwienia jako uświęcenia?

Gdy przyglądnąć się bliżej problemowi pod względem nauczania, to jest on w rzeczywistości znacznie bardziej skomplikowany, niż by się mogło wydawać. Należy podkreślić, że istnieje wiele złożonych kwestii i pytań odnoszących się do tej kontrowersji, choćby pytania natury logicznej - jeśli człowiek jest sprawiedliwy, to jak jednocześnie może być grzesznikiem? czy też doktrynalnej - cóż to za Bóg, który usprawiedliwia człowieka i jednocześnie nie wyzwala go z grzechu? Celem artykułu jest próba przedstawienia zagadnienia simul iustus et peccator w takim świetle, aby skutecznie dążyć do przełamania ekumenicznego impasu w tej materii i widzieć w perspektywie czasu zarysowującą się jedność obu wspólnot chrześcijańskich, nie pomijając obu tradycji. Zostanie podjęta próba odpowiedzi na pytanie, w jaki sposób katolicy i luteranie powinni podejść do istoty zagadnienia oraz do nauczania w tym względzie, aby zniwelować trwającą rozbieżność i podział Kościołów? Ponieważ źródłem komplikacji jest różne rozumienie pojęcia grzechu przez oba Kościoły, słuszna będzie analiza pod kątem pożądliwości (concupiscentia) ${ }^{3}$.

Istniejący między konfesjami eklezjalnymi spór można przezwyciężyć i tym samym realizować jedność Kościoła, jeśli ową formułę będzie się postrzegać w kategorii opinii teologicznej (tzw. theologoumenon). Pojęcie to nie ma bezpośredniego potwierdzenia w Piśmie Świętym i nauczaniu Magisterium Kościoła i nie ma charakteru wiążącego, ale rzuca światło na rozumienie doktryny. $\mathrm{W}$ takiej perspektywie owa opinia teologiczna

Por. W. Pannenberg, Die Gemeinsame Erklärung zur Rechtfertigung aus römisch-katholischer Sicht, [w:] Zur Zukunft der Ökumene. Die „Gemeinsame Erklärung zur Rechtfertigungslehre”, hrsg. von B. Hilberath, W. Pannenberg, Regensburg 1999, s. 42. 
może zostać zaakceptowana przez obu rozmówców dialogu, choć każdy $z$ nich może inaczej brać pod uwagę treść tego oświadczenia ${ }^{4}$. Istnieje duża szansa, że zrozumienie powyższej kontrowersji w takiej kategorii może przyczynić się do odpowiedzenia na wiele pytań pod jej adresem i zagwarantować zachowanie jedności Kościołów bez pomniejszania nauki któregoś z nich. Z jednej strony taka jedność jest owocem zbawczej śmierci Jezusa Chrystusa, ale z drugiej wymaga od katolików i luteranów dyscypliny poświęcenia, polegającej na przyjęciu jako uzasadnienia opinii teologicznej drugiego Kościoła. Nie idzie więc o wskazanie, która strona ma rację czy jest nie $\mathrm{w}$ porządku w odniesieniu do złożonego problemu, ale jak te dwie tradycje odmiennie pojmują pojęcie simul iustus et peccator i jak ono jako theological statement może pomóc złagodzić czy nawet rozwiać doktrynalne napięcia oraz wzmocnić jedność Kościołów. Dla lepszego zrozumienia tego zagadnienia pomocne będzie ukazanie jego historyczno-teologicznego kontekstu ${ }^{5}$.

\section{Święty Augustyn a pożądliwość}

Idea, że wierzący człowiek jest jednocześnie usprawiedliwiony i grzeszny, najczęściej kojarzy się z osobą i dziełem Marcina Lutra (1483-1546). Warto jednak zaznaczyć, iż nie została ona stworzona przez ojca szesnastowiecznej reformacji, ale odkryta na nowo. Za prekursora tej nauki powszechnie uważa się św. Augustyna z Hippony (354-430). Z kolei głównym obrońcą tej idei stał się Luter przez radykalne nauczanie i piśmiennictwo w tym temacie. Bez wahania stwierdził on, że nie jest ani pierwszym, ani jedynym człowiekiem, który o tym mówi. Przywołuje stanowisko św. Augustyna, że każdy grzech zostaje odpuszczony w sakramencie chrztu nie tak, że już nie istnieje, ale tak, że nie jest już dłużej przypisany ${ }^{6}$.

4 Por. R. McBrien, Catholicism, Washington 1996, s. 542.

5 Por. V. Mshanga, Simul iustus et peccator, "Journal of Ecumenical Studies” vol. 45/4 (2010), s. 578-580; P. Mey, A call to conversion, [w:] Rethinking ecumenism, ed. F. Bakker, Meinema-Zoetermeer 2004, s. 211-228.

6 Por. M. Luther, Against Latomus, [w:] Luther's works, vol. 32, eds. J. Pelikan, H. Oswald, H. Lehmann, Philadelphia 1999, s. 209; W. Lazareth, Christians in society: Luther, the Bible, and 
Jeżeli idzie o spostrzeżenia Augustyna dotyczące simul iustus et peccator, wyraźnie wypływają one z jego refleksji teologicznej na temat grzechu pierworodnego, łaski i wybrania. Doctor gratiae stoi na stanowisku, że nawet po chrzcie w usprawiedliwionym pozostają skutki grzechu pierworodnego, które nazywają się pożądliwością. Z perspektywy zaś soteriologicznej concupiscentia jest przyczyną wszystkich kolejnych grzechów. Biskup z Hippony definiuje pożądliwość jako przewrotność i brak porządku, który jest odwróceniem się od Stwórcy bardziej doskonałego, a nieuporządkowanym zwróceniem się do stworzeń, które są niższe w stosunku do Niego. Z tego względu rdzeniem pożądliwości - według niego - jest lekceważący stosunek do Boga ${ }^{7}$. Dostrzegalna jest tutaj relacja między pożądliwością a jednoczesną sprawiedliwością i grzesznością, związana ściśle z Augustynową koncepcją soteriologii, w której rozróżnia on grzech pierwotny, popełniony przez pierwszych rodziców w raju, i grzech pierworodny, będący skutkiem grzechu rajskiego, przechodzący na potomstwo Adamowe. Przed upadkiem Adama ludzkość została pobłogosławiona przez Boga i cieszyła się komunią z Nim, a po grzechu pierwszych rodziców stała się podległa grzechowi i winie, co ujawniło się bezradnościąa

Augustyn jest głęboko przekonany o skutkach tego grzechu, które przeszły na wszystkich ludzi, ponieważ w chwili upadku symbolicznie cała ludzkość była obecna w Adamie. Cały rodzaj ludzki w jakiś sposób uczestniczy w grzechu Adama, bo każdy, kto się narodził z jego nasienia, był już obecny w nim w tajemniczy sposób. Dlatego grzech wszedł na świat przez jednego człowieka, a przez grzech - śmierć, która przeszła na wszystkich ${ }^{9}$. Powyższe sformułowanie różnie interpretowano. War-

social ethics, Minneapolis 2001, s. 125-129.

Por. Augustyn, Do Symplicjana o różnych problemach, [w:] De sermone Domini in monte, tłum. F. Ryznar, J. Sulowski, Warszawa 1989, s. 159-161 (Pisma Starochrześcijańskich Pisarzy, 48); J. Couenhoven, St. Augustine's doctrine of original sin, „Augustinian Studies” 36/2 (2005), s. 359-396.

Por. E. Stump, N. Kretzmann, The Cambridge companion to Augustine, Cambridge 2001, s. 40-48; E. Bonaiuti, G. La Piana, The genesis of St. Augustine's idea of original sin, „Harvard Theological Review” vol. 10/2 (1917), s. 159-175; Augustyn, Państwo Boże, przeł. W. Kubicki, Kęty 1998, s. 530-531.

9 Por. Augustyn, Państwo Boże, dz. cyt., s. 487; J. Couenhoven, St. Augustine's doctrine of original $\sin$, dz. cyt., s. 363. 
to jednak zauważyć, że Augustyn tłumaczy je jako świadectwo ludzkiej solidarności z grzechem Adama. Z kolei grzech pierworodny i jego skutki (śmierć) mogą być oczyszczone jedynie poprzez łaskę chrztu świętego. W De civitate Dei biskup z Hippony zapewnia również, że przez chrzest człowiek jest pozbawiony grzechu pierworodnego. Nikt nie może wejść do królestwa niebieskiego z wyjątkiem człowieka, który narodził się z wody i Ducha Świętego, ale nawet po usprawiedliwieniu pragnienie zła lub pożądliwość pozostają w usprawiedliwionym ${ }^{10}$.

Warto podkreślić, że św. Augustyn - w przeciwieństwie do Lutra - wykazuje się dużym optymizmem odnośnie do pożądliwości ciała (concupiscentia carnis), która nawet jeśli prowadzi do grzechu, to można i należy ją pokonać dzięki łasce Bożej i dobrym pragnieniom ducha, oraz do pożądliwości ducha (concupiscentia spiritu). Co więcej, nie przyrównuje pożądliwości do grzechu pierworodnego. Twierdzi, że jest to oznaka kary za grzech pierworodny. W związku z powyższym jego stanowisko względem pożądliwości ciała jest takie, że po pierwsze, nawet jeśli nazywa się ją grzechem i nosi ona taką nazwę, to nie dlatego, że jest grzechem, ale dlatego, że jest owocem grzechu. Po drugie, owa pożądliwość ciała jest sama w sobie odpuszczona w chrzcie świętym w taki sposób, że chociaż jest obecna w tych, którzy się rodzą, to nie szkodzi tym, którzy są odrodzeni, ponieważ ich winy przez urodzenie zostały odpuszczone przez odrodzenie. Z tego powodu nie jest już grzechem, choć nazywa się grzechem. Mimo że nieuporządkowane pragnienia pozostają, to zarówno poczucie winy, jak i grzechu zostają odpuszczone ${ }^{11}$.

Wbrew tej opinii ojcowie soboru trydenckiego precyzują pojęcie iustificatio, które nie tylko polega na odpuszczeniu grzechów, lecz także na uświęceniu i odnowieniu człowieka wewnętrznego przez chętne przyjęcie łaski oraz darów, wskutek czego człowiek z niesprawiedliwego staje się sprawiedliwy, a z wroga staje się przyjacielem, aby być spadkobiercą

10 Por. Augustyn, Państwo Boże, dz. cyt., s. 480-481; A. Lane, Justification by faith in Catholic-Protestant dialogue, New York 2006, s. 45.

11 Por. V. Mshanga, Simul iustus et peccator, dz. cyt., s. 580-583; M. Lamberigts, A critical evaluation of critiques of Augustine's view of sexuality, [w:] In Augustine and his critics, eds. R. Dodaro, G. Lawless, London 2000, s. 176-197. 
życia wiecznego w nadziei ${ }^{12}$. Dlatego też uderzające jest, iż wspólne dla św. Augustyna, Marcina Lutra i Tridentinum było przekonanie, że w usprawiedliwieniu chrześcijanin jest wewnętrznie odnowiony, zregenerowany i włączony w Chrystusa faktycznie i w sposób pełny.

\section{Odkrycie Marcina Lutra i reformacyjne reperkusje}

Pogląd Marcina Lutra, jak można było przewidzieć, jest tożsamy z wizją św. Augustyna, że przez grzech pierwszych rodziców w raju rodzaj ludzki stał się grzeszny i niezdolny do zbawienia. Jednakże miłosierny Bóg przez Jezusa Chrystusa przebaczył grzesznikom i okazał im swoją sprawiedliwość. Idea simul iustus et peccator dość wcześnie pojawia się w pismach Lutra: w Komentarzu do Listu do Rzymian (1515/1516) i Komentarzu do Listu do Galatów (1516/1517). Luter ma zamiłowanie do paradoksów, pojmowanych w biblijnym sensie jako coś, co przed Bogiem jest święte, a przed światem głupie. Stosuje przeciwstawne określenia do usprawiedliwiającego Boga i wobec człowieka. W dyspucie na temat iustificatio (1536), podobnie jak w swoich wykładach na temat Listu do Rzymian stoi na stanowisku, że człowiek jest usprawiedliwiony przez wiarę i otrzymuje odpuszczenie grzechów, ale pozostaje jednocześnie sprawiedliwy i grzeszny (simul iustus et peccator). Oznacza to - w rozumieniu Lutra - że o ile grzesznicy zostają uznani za świętych przed Bogiem i przez wzgląd na Chrystusa stają się sprawiedliwi, o tyle jeżeli w dalszym ciągu popełniają grzechy, pozostają grzesznikami. Mimo wszystko Bóg rzeczywiście działa w taki sposób, że grzech nie pozostaje grzechem, ponieważ oczyszcza człowieka z niego i całkowicie mu przebacza. Analizując Modlitwę Pańską, Luter wskazuje, że święci (niejako wszyscy chrześcijanie) proszą Boga każdego dnia o przebaczenie. Gdyby nie mieli grzechu, to bezzasadnym byłaby modlitwa: „I odpuść nam nasze winy”. Stwierdza również, że tak naprawdę wierzą-

12 Por. Sobór Trydencki, Dekret o usprawiedliwieniu, rozdz. 7a, [w:] Dokumenty Soborów Powszechnych: tekst łaciński i polski, t. 4: (1511-1870) Lateran IV, Trydent, Watykan I, układ i oprac. A. Baron, H. Pietras, tłum. A. Baron i in., Kraków 2004, s. 295; W. Medwid, Usprawiedliwienie $w$ dialogu katolicko-luterańskim, dz. cyt., s. 92-95. 
cy są już całkowicie sprawiedliwi, ale rzeczywistość tę rozumie w kontekście eschatologicznym i dopiero śmierć jako wyzwolenie pokaże człowiekowi nowe horyzonty darowanej przez Chrystusa wiary ${ }^{13}$.

Swoją wizję problematycznego zagadnienia Luter zaprezentował podczas obalania argumentów teologów z Uniwersytetu w Louvain (Belgia), którzy na czele z Jakubem Latomusem otwarcie potępili jego pisma. Latomus utrzymywał, że w usprawiedliwionych po chrzcie nie pozostaje żaden grzech $^{14}$. Natomiast Luter zgadza się, że chrzest usuwa wszystkie grzechy, bo rzeczywiście się tak dzieje, ale robi zastrzeżenie, iż ów sakrament nie usuwa istoty grzechu i nawet po Bożym przebaczeniu nadal pozostaje grzech, choć nie jest on mu przypisany. Trzeba zaznaczyć, iż dla teologa z Wittenbergi grzech pozostający w usprawiedliwionym człowieku jest ze swej natury rzeczywiście grzechem, ale tylko pod względem istoty, a nie w jego ilości, jakości czy działaniu, gdyż jest on całkowicie bierny ${ }^{15}$. Dlatego wierzący nie jest jeszcze w pełni człowiekiem wiary, w którym żyje Chrystus, lecz nadal pozostaje starym Adamem (człowiekiem z ciała) i w tej bezradności każdego dnia potrzebuje Bożego przebaczenia. Tak więc realność grzechu trwa przez całe życie ziemskie aż do paruzji, kiedy wszyscy wybrani staną się sprawiedliwi w sposób doskonały.

Argumentując swoje przekonanie, że wierzący jest jednocześnie sprawiedliwy i grzeszny, Luter stosuje metaforę chorego i lekarza. Według niego usprawiedliwienie dokonuje się podobnie jak w przypadku chorego człowieka i lekarza obiecującego mu pewność wyzdrowienia. Podczas przebiegu leczenia chory ma wypełniać zalecenia lekarza. Ma przy tym nadzieję, że po pierwsze obiecane wyzdrowienie (ze swoich grzesznych skłonności) i po drugie powstrzymanie się od tych rzeczy, które zostały mu zakazane, aby w żaden sposób nie utrudniały obiecanego powrotu do

13 Por. M. Luther, Lectures on Romans: glosses and scholia, [w:] Luther's Works, dz. cyt., vol. 25, s. 260; M. Luther, The Disputation concerning justification (1536), [w:] Luther's Works, dz. cyt., vol. 34, s. 167; R. Olson, The story of Christian theology, Westmont 1999, s. 385-390; M. Mullet, Martin Luther, Oxford 2004, 225-227.

14 Por. G. Kawerau, Latomus, Jacobus, [w:] The new Schaff-Herzog encyclopedia of religious knowledge, London-New York 1910, vol. 6, s. 420-421.

15 Por. M. Luther, Against Latomus, [w:] Luther's Works, dz. cyt., vol. 32, s. 201. 209; O. H. Pesch, Die Theologie der Rechtfertigung bei Martin Luther und Thomas von Aquin, Mainz 1985, s. 956-961. 
zdrowia lub pogłębienia się choroby, staną się faktem. W swym wywodzie zadaje pytanie, czy teraz jest to chory, czy zdrowy człowiek? Odpowiadając, stwierdza, że jest on zarówno chory, jak i zdrowy. Z jednej strony ów człowiek jest rzeczywiście chory, ale z drugiej strony jest zdrowy (traktowany jako sprawiedliwy) ze względu na pewność obietnicy lekarza, któremu ufa i który uznaje go już za wyleczonego, ponieważ jest przekonany, że będzie go w stanie wyleczyć16.

Powyższa nauka Lutra na temat usprawiedliwionego, będącego jednocześnie sprawiedliwym i grzesznym, budzi pewne wątpliwości, które stanowią fundament kontrowersji: Czy w takim statusie wierzącego jest realna jego ontologiczna przemiana? Czy może być ktoś całkowicie sprawiedliwy albo całkowicie grzeszny, czy też częściowo sprawiedliwy albo częściowo grzeszny? Czy osoba, która otrzymała usprawiedliwienie, w dalszym ciągu jest grzeszna? Dla lepszego wyjaśnienia i głębszego zrozumienia wizji simul iustus et peccator w ujęciu ojca reformacji należy wprowadzić pomocne określenia i rozróżnienia w kwestii, kiedy wierzący może być traktowany równocześnie jako sprawiedliwy i grzeszny. Pierwsza sytuacja ma miejsce, gdy usprawiedliwiony jest postrzegany przez pryzmat powyższych kategorii w sensie bycia częściowo sprawiedliwym, a częściowo grzesznikiem. Druga sytuacja, gdy jest on albo zupełnie prawy, albo zupełnie grzeszny ${ }^{17}$.

Warto również zastosować, z zakresu filozofii, rozróżnienie pomiędzy ontologią substancji a relacyjną ontologią. Ontologia substancji jawi się jako relacja bytu bądź tożsamość rzeczy z uwzględnieniem ich indywidualnych właściwości, a nie jej stosunku do innych bytów. Relacyjna ontologia jest relacją bytu rzeczy w zakresie jej relacji do innych rzeczy, a przynajmniej relacją, w której stosunki bytów ze sobą tworzą ich byt jako jednostki. Tak więc w relacyjnym sensie coś jest tym, czym jest w stosunku do innego przedmiotu. Pozostaje kwestia, czy przy nauce simul iustus et peccator nie powstaje wrażenie, że tak naprawdę nowe pozostaje sta-

16 Por. M. Luther, Lectures on Romans: glosses and scholia, dz. cyt., vol. 25, s. 62-63; T. Dorman, Justification as healing, ,Quodlibet Journal of Christian Theology and Philosophy” 2 (2000), s. 1-12.

17 Por. M. Luther, The private mass and the consecration of the priests, [w:] Luther's Works, dz. cyt., vol. 38, s. 149; P. Althaus, The theology of Martin Luther, Philadelphia 1970, s. 227-230. 
rym, co jest jednym z poważniejszych zastrzeżeń strony wobec teologii luterańskiej. W rozumieniu tych ostatnich nie chodzi o dwa częściowe aspekty, ale o całość. Tylko wtedy, gdy cały człowiek postrzegany będzie jako grzesznik (totus homo peccator est), rzeczywistość usprawiedliwienia zostanie zachowana bez względu na to, czy przyjmujemy prawnicze czy dynamiczne rozumienie zbawienia. Tylko wtedy, gdy człowiek oświecony Duchem Świętym pozna, że jest grzesznikiem, może przyjąć i doświadczyć Bożej obietnicy i działania. Chrześcijanie są grzesznikami, wiedzącymi o swojej grzeszności ${ }^{18}$.

Powyższe rozróżnienia ułatwią próbę odczytania luterańskiego pojęcia simul iustus et peccator. Przez pryzmat relacyjnej ontologii usprawiedliwiony jest cały sprawiedliwy i cały grzeszny. Zakłada to, w rozumieniu luteranów, że tożsamość chrześcijanina nie jest już definiowana w kategoriach natury wierzącego, ale pod względem stosunku do Chrystusa. Dzięki tej relacji wierzący może być traktowany jako cały sprawiedliwy, jednak nie ze względu na to, co ma w sobie, ale z uwagi na to, co znajduje się w Chrystusie. Ze względu na siebie, mówiąc w kategoriach ontologii substancji, jest wciąż cały grzesznikiem. Dlatego też, podkreśla Luter, człowiek jest sprawiedliwy przez odpuszczenie grzechów, to znaczy poprzez wyrok Boga, który przyjmuje go jako sprawiedliwego ze względu na Chrystusa, i jest on grzesznikiem w sobie, który teraz istnieje jako człowiek. Usprawiedliwiony człowiek chce być w przyjaźni z Bogiem, ale przeszkadza mu w tym grzech, tkwiący w nim tak bardzo, że może uznać go za własny, choć nie ma absolutnej mocy nad człowiekiem, ponieważ sprawiedliwość Chrystusa jest silniejsza od ludzkiej ułomności. Mówiąc inaczej: każdy, kto znajduje się w mocy grzechu, pozostaje grzesznikiem ${ }^{19}$. Po pierwsze, relacyjne podejście (przy całkowitej grzeszności człowieka)

18 Por. W. Wildman, An introduction to relational ontology, [w:] The Trinity and an Entangled world: relationality in physical science and theology, eds. J. Polkinghorne, J. Zizioulas, Grand Rapids 2010, s. 55-73; M. Loux, Metaphysics: a contemporary introduction, Oxford 2002, s. 106110; V. Mshanga, Simul iustus et peccator, dz. cyt., s. 583-584.

19 Por. P. Althaus, The theology of Martin Luther, dz. cyt, s. 242; H. U. von Balthasar, Skizzen zur Theologie, Freiburg 1971, t. 2, s. 203-205; C. Trueman, Simul peccator et justus: Martin Luther and justification, [w:] Justification in perspective: historical developments and contemporary challenges, ed. B. McCormack, Grand Rapids-Edinburgh 2006, s. 73-90. 
wyklucza jakąkolwiek zasługę ze strony wierzącego. To także uniemożliwia uwzględnienie usprawiedliwienia wierzących w kategoriach stawania się sprawiedliwymi samymi w sobie. Po drugie, traktowanie grzesznika jako po części sprawiedliwego i po części grzesznego zakłada ontologię substancji, w której jest więcej miejsca na podjęcie wewnętrznej sprawiedliwości wierzącego, uwzględniając wewnętrzną odnowę i dobre uczynki dzięki działaniu Ducha Świętego ${ }^{20}$.

To drugie podejście można dostrzec w traktacie teologicznym Lutra dotyczącym wolności chrześcijanina (De libertate christiana ${ }^{21}$ ). Pozostając w nurcie nauczania św. Pawła (1 Kor 15, 20-28; 1 Tes 4, 13-18), stwierdza, że istnieje w wierzącym część, która jest już w Chrystusie, w niebie, ale widzi w nim również część, która jest jeszcze na ziemi, w ciele. To pokazuje dialektykę pomiędzy ,już” a ,jeszcze nie”, tym samym jest się grzesznikiem w rzeczy samej (in re), ale usprawiedliwionym w nadziei (in spe). Kontynuując rozważanie, Luter metaforycznie podkreśla, że osoba, która wierzy w Chrystusa, jest sprawiedliwa i święta przez boskie przypisanie, jak i wywyższona w łonie Ojca i przyozdobiona najlepszą szatą, ale jej stopy wystające spod ubrania gdy tylko może, gryzie szatan. Następnie walczy ona i woła, zdając sobie sprawę, że jest wciąż z krwi i kości i że diabeł jest nadal obecny i wciąż nęka, dopóki człowiek wzrasta w świętości i podnosi się z nikczemnego świata $\mathrm{zła}^{22}$. Trzeba w tym miejscu zaznaczyć, iż dla Lutra osoba jest całkowicie grzesznikiem przed usprawiedliwieniem, w jego trakcie i po nim, ponieważ nie ma na ziemi człowieka sprawiedliwego, który czyni dobrze i nie grzeszy. Człowiek znajduje się w dwóch miejscach na raz: jeśli wierzy, to jest u Chrystusa, jeśli wątpi - popada w grzech. Z punktu widzenia wiary - miłość Boga ma bezgraniczną przewagę nad niewiarą ${ }^{23}$.

20 Por. O. Bayer, Martin Luther's theology: a contemporary interpretation, Grand Rapids 2008, s. 155-158; E. Jüngel, Das Evangelium von der Rechtfertigung des Gottlosen als Zentrum des christlichen Glaubens, Tübingen 1998, s. 185-189.

${ }_{21}$ Por. M. Luther, De libertate christiana, [w:] Martin Luthers Werke. Weimarer Ausgabe, „Böhlaus Nachfolger” 2003, vol. 7, s. 49-73.

22 Por. M. Luther, Lectures on Romans: glosses and scholia, dz. cyt., vol. 25, s. 258.

23 Por. M. Luther, Against Latomus, dz. cyt., vol. 32, s. 180; V. Mshanga, Simul iustus et peccator, dz. cyt., s. 584-585. 


\section{Koncepcja simul iustus et peccator w dialogu katolicko-luterańskim}

W dialogu katolicko-luterańskim w drugiej połowie ubiegłego stulecia kontrowersja jednoczesnej sprawiedliwości i grzeszności wierzącego była zazwyczaj podejmowana w kontekście dialogów ekumenicznych dotyczących usprawiedliwienia. Po raz pierwszy tę kwestię omówiono podczas drugiej fazy rozmów luterańsko-katolickich w 1983 roku w USA pod patronatem Światowej Federacji Luterańskiej, Krajowej Konferencji Biskupów Katolickich USA i Kościoła Luterańskiego z Synodem w Missouri ${ }^{24}$.W trakcie dialogu obie wspólnoty eklezjalne stwierdziły, że usprawiedliwiony człowiek jest rzeczywiście odrodzony, odnowiony i uświęcony, a więc jest nowym stworzeniem. W związku z tym obie strony dialogu określiły stan iustificatio, które jest przejściem z niełaski i nieprawości do łaski i sprawiedliwości w oczach Boga oraz jest ono całkowicie dziełem Boga. Przez usprawiedliwienie wierzący zostaje poczytany za sprawiedliwego i uczyniony sprawiedliwym. Dlatego usprawiedliwienie nie jest prawną fikcją. Usprawiedliwiając, Bóg sprawia to, co obiecał: odpuszcza grzechy i czyni ludzi prawdziwie sprawiedliwymi ${ }^{25}$.

Jednakże luteranie, broniąc swojego stanowiska, twierdzili, że nawet jeśli człowiek jest odnowiony i uświęcony, to pozostaje jednocześnie sprawiedliwy i grzeszny, stąd wynika potrzeba ustawicznej walki z grzechem. Natomiast katolicy podtrzymywali, że w chrzcie każdy grzech, także jego skutki, jak i poczucie winy (reatus culpae) zostają oczyszczone.Jednak usprawiedliwieni popadają od czasu do czasu w grzech codziennego życia, a działanie Ducha Świętego nie uwalnia ich od trwającej przez całe życie walki z grzesznymi skłonnościami. Pożądanie i inne skutki grzechu pierworodnego i grzechu osobistego pozostają w usprawiedliwionym, który z tego powodu musi modlić się codziennie o Boże przebaczenie. Warto zaznaczyć wspólne stwierdzenie Kościołów, że Duch Święty nie

${ }^{24}$ Por. W. Medwid, Usprawiedliwieniew dialogu katolicko-luterańskim, dz. cyt., s. 197-200; A. Napiórkowski, Bogactwo łaski a nędza grzesznika, dz. cyt., s. 308-309.

${ }_{25}$ Por. Justification by faith (common statement), [w:] Justification by Faith. Lutherans and Catholics in Dialogue VII, eds. H. G. Anderson, T. A. Murphy, J. A. Burgess, Minneapolis 1985, nr 156; A. Lane, Justification by faith in Catholic-Protestant dialogue: an Evangelical assessment, dz. cyt., s. 217-220. 
zwalnia chrześcijanina z ustawicznej walki przeciwko grzesznym skłonnościom ${ }^{26}$. W sumie rozmowy za oceanem zakończyły się rozbieżnymi punktami obaw w odniesieniu do simul iustus et peccator, a perspektywy rzeczywiście wskazują na niezgodność. W tej sytuacji katolicy pozostali zaniepokojeni etykietowaniem pożądliwości grzechu, a luteranie zastanawiali się, czy katolicy nie przeoczyli powagi grzechu ${ }^{27}$.

W kolejnej fazie rozmów interesująca nas kwestia została podjęta na terenie niemieckojęzycznym ${ }^{28}$. Wciąż chodziło o problem, w jaki sposób można mówić u usprawiedliwionego o grzechu bez ograniczania rzeczywistości zbawienia? Mając za podstawę wcześniejszy dialog, oba Kościoły uważają, że usprawiedliwiony jest odnowiony i uświęcony, ale pozostaje w nim skłonność do grzechu, czyli pożądliwość. Ponadto concupiscentia rzeczywiście jest nastawieniem przeciw Bogu (Gottwidrigkeit), jednak nie oddziela człowieka od Niego, ponieważ zostało to odpuszczone. Dla reformatorów pożądliwość rozumiana jest jako grzech, nie w sensie etycznym, jako realny grzech, ale jako grzech zakorzeniony w osobie, który leży u podstaw wszystkich etycznych grzechów, i może być również stosowany jako termin dla grzechu pierworodnego ${ }^{29}$. Po drugie, po chrzcie pożądliwość staje się normą grzechu lub grzechem poskromionym (peccatum regnatum). Natomiast katolicy, wierni Soborowi Trydenckiemu, utrzymują, że pożądliwość, którą Apostoł czasami nazywa grzechem $(\mathrm{Rz} 6,12)$, nie jest już rozumiana jako grzech we właściwym znaczeniu, ale ma swoje źródło w grzechu i do niego nakłania. W tym względzie rzeczywistość zbawienia wymaga zakwestionowania, jakoby concupiscentia miała charakter grzechu ${ }^{30}$.

26 Por. Justification by faith (common statement), dz. cyt., nr 102.

${ }_{27}$ Por. G. Lindbeck, A question of compatibility: a Lutheran reflects on Trent, [w:] Justification by Faith. Lutherans and Catholics in Dialogue VII, dz. cyt., s. 230-240; V. Mshanga, Simul iustus et peccator, dz. cyt., s. 585.

28 Por. Ökumenischer Arbeitskreis Evangelischer und Katholischer Theologen, Lehrverurteilungen - Kirchentrennend? Materialien zur Lehre von den Sakramenten und vom Kirchelichen, Hg. K. Lehmann, W. Pannenberg, Bd. 1-4, Freiburg-Göttingen 1986.

${ }_{29}$ Por. Ökumenischer Arbeitskreis Evangelischer und Katholischer Theologen, Lehrverurteilungen - Kirchentrennend?..., dz. cyt., t. 1: Rechtfertigung, Sakramente und Amt im Zeitalter der Reformation und heute, nr 35, 52.

30 Por. J. Lipniak, Ekumeniczne usprawiedliwienie podzielonych grzeszników, Świdnica 2006, s. 34-36; Sobór Trydencki, Dekret o grzechu pierworodnym, rozdz. 5b-c, [w:] Dokumenty Soborów Powszechnych..., dz. cyt., s. 240. 
Ta pozycja jest diametralnie sprzeczna z luterańskim nauczaniem w sprawie statusu ochrzczonego wierzącego. Ciekawą konkluzją w tej fazie dialogu katolicko-luterańskiego były stwierdzenia, że z jednej strony nie wydaje się owocne omówienie kwestii pozostającego w wierzącym grzechu w rozumieniu protestanckim, jedynie w ramach tej koncepcji. $Z$ drugiej zaś strony, biorąc najostrzejsze rozeznanie natury ludzkiej jako całości, teologia katolicka stała się znacznie bliżzza protestanckiej wizji pojęcia pożądliwości. Nie są to tendencje, które występowały w średniowieczu i odłączały fizyczną naturę człowieka, naznaczoną pożądliwością, od natury duchowej, uwolnionej od pożądliwości dzięki usprawiedliwieniu. Katolicy określili pożądliwość, nadal obecną w usprawiedliwionym, jako opozycję wobec Boga, kwalifikując ją tym samym jako grzech ${ }^{31}$. Należy bez wątpienia podkreślić, że te dwa spostrzeżenia odzwierciedlają dwie myślowe struktury osadzone w dwóch tradycjach. Niemniej jednak kontrowersja jednoczesnej sprawiedliwości i grzeszności wierzącego nadal pozostała jedną z zaległych różnic między Kościołami ${ }^{32}$.

W podpisanej przez katolików i luteranów Wspólnej deklaracji w sprawie nauki o usprawiedliwieniu w kwestii grzeszności usprawiedliwionego strona luterańska stoi na stanowisku, że chrześcijanin jest w pełni sprawiedliwy, ponieważ Bóg przez słowo i sakrament przebacza mu grzechy oraz przyznaje sprawiedliwość Chrystusa, która w wierze staje się jego własnością i czyni go w Chrystusie sprawiedliwym przed Bogiem. Natomiast dzięki prawu poznaje, że nadal pozostaje grzesznikiem i że grzech jeszcze w nim mieszka ${ }^{33}$. Na podstawie relacyjnej ontologii, patrząc na Chrystusa, wierzący jest usprawiedliwiony, z kolei w kategoriach ontologii substancji, patrząc na siebie, usprawiedliwiony jest grzesznikiem. Stoi to w sprzeczności z nauczaniem Soboru Trydenckiego, a mianowicie, że usprawiedliwio-

31 Por. Lehrverurteilungen - Kirchentrennend?..., dz. cyt., t. 1, nr 46; K. Karski, Protestanci i ekumenizm. Wkład spadkobierców Reformacji w dzieło jedności, Warszawa 2001, s. 297.

32 Por. J. Lipniak, Ekumeniczne usprawiedliwienie podzielonych grzeszników, dz. cyt., s. 181187; V. Mshanga, Simul iustus et peccator, dz. cyt., s. 586.

33 Por. Wspólna deklaracja w sprawie nauki o usprawiedliwieniu (1997). Projekt ostateczny, nr 29, „Studia i Dokumenty Ekumeniczne” 2 (1997), s. 67; Gemeinsame Erklärung zur Rechtfertigungslehre, [w:] Gemeinsame Erklärung zur Rechtfertigungslehre. Ein Kommentar für Ökumenische Forschung, Straßburg 1997, s. 69; W. Medwid, Usprawiedliwienie w dialogu katolicko-luterańskim, dz. cyt., s. 269-270. 
ny jest naprawdę sprawiedliwy i wewnętrznie odnowiony, a tym samym grzech nie pozostaje w nim. W katolickim rozumieniu concupiscentia nie jest grzechem i ponadto nie może i nie szkodzi człowiekowi usprawiedliwionemu, pod warunkiem że nie zgadza się na nią. Klarownie wyjaśniają tę sytuację ojcowie soboru w Trydencie w dekrecie o grzechu pierworodnym, stwierdzając, że uznają i zgadzają się, iż w ochrzczonych pozostaje pożądliwość (zarzewie grzechu), która jest pozostawiona wierzącym dla walki, nie może szkodzić tym, którzy jej nie dają przyzwolenia i mężnie opierają się jej z pomocą łaski Jezusa Chrystusa (2 Tm 2, 5). Odnośnie do pożądliwości, którą Apostoł niekiedy nazywa grzechem (Rz 6, 12n), oświadczają, że Kościół katolicki nigdy nie uważał, jakoby u ochrzczonych była prawdziwym i właściwym grzechem, lecz tak jest nazwana, bo jest pozostałością po grzechu i do niego skłania ${ }^{34}$.

Jak można dostrzec, powyższe stanowisko ojców soborowych, że pożądliwość nie powinna być rozumiana jako grzech, jest rozbieżne zarówno z koncepcją św. Augustyna, jaki Marcina Lutra dotyczącą concupiscencji. Luteranie uznają pożądliwość jako rzeczywisty grzech. Dla nich jest ona mięk ki m podbr zus ze m (soft underbelly), które sprawia, że chrześcijanin jest podatny na grzech ${ }^{35}$. W związku z tym, z punktu widzenia luterańskiego, są dwa sposoby, aby mówić o niekompletności odnowy życia chrześcijańskiego. Po pierwsze - ze względu na grzech, który pozostaje w usprawiedliwionym - człowiek jest nieustannie narażony na moc grzechu i rzeczywiście jest grzesznikiem (Rz 6, 12-14). W tym punkcie katolicy i luteranie nigdy nie byli zgodni. Po drugie, usprawiedliwiony nie jest wolny od pożądań ciała i przez całe życie musi walczyć z grzechem $(\mathrm{Ga} 5,16)$. Do zrozumienia tego pomocne będzie zacytowanie wezwania św. Pawła z Listu do Rzymian: „Niechże więc grzech nie króluje w waszym śmiertelnym ciele, poddając was swoim pożądliwościom" (Rz 6, 12). W drugiej sytuacji oba Kościoły nawiązały nić porozumienia. Można powiedzieć,

\footnotetext{
34 Por. Sobór Trydencki, Dekret o grzechu pierworodnym, rozdz. 5b-c, dz. cyt., s. 240.

35 Por. D. Truemper, Introduction to the Joint declaration on the doctrine of justification, [w:] Rereading Paul together: Protestant and Catholic perspectives on justification, ed. D. Aune, Grand Rapids 2006, s. 39; Lutheran Church Missouri Synod, The Joint declaration on the doctrine of justification in confessional Lutheran perspective, "Journal of Evangelical Theological Society" 44 , no. 3 (1999), s. 15-19.
} 
że te dwie wizje stanowią niejako parametry analizowanej kontrowersji. Ostatecznie w Dodatku do Wspólnej deklaracji zostało potwierdzone niepełne, wzajemne zrozumienie osiągnięte $w$ tej dziedzinie ${ }^{36}$.

\section{Uwagi Karla Rahnera}

Ciekawe uwagi i zastrzeżenia na temat interesującego nas problemu pojawiają się w teologicznym ujęciu Karla Rahnera. Po pierwsze, podkreśla on, że usprawiedliwienie jako zbawczy proces stwarza coś nowego, natomiast idea simul iustus et peccator zamazuje zbawcze oddziaływanie usprawiedliwienia, w którym wszystko jest prawdziwie nowe. Człowiek staje się sprawiedliwym, którym przedtem nie był. Po drugie, owa idea nie oddaje w sposób adekwatny stanu usprawiedliwionego człowieka. Opowiada się on za docenianiem Bożego usprawiedliwienia, którego nie można zredukowaćjedynie do osobistego doświadczenia. Nie wiara i doświadczenie pojedynczego człowieka są istotne, ale czyn Boga. Ponadto Rahner krytykuje również jurysdykcyjne ujęcie reformacyjnej nauki o usprawiedliwieniu, mówiącej o sprawiedliwości jako przypisaniu (imputatio) sprawiedliwości na wzór wyroku uniewinniającego. Podkreśla uświęcenie jako istotną część usprawiedliwienia, mówiąc o przebóstwieniu i przemienieniu człowieka. Według niemieckiego teologa luterańskie rozumienie kontrowersyjnej formuły jest nie do przyjęcia, ponieważ swojąjednoczesnością sprawiedliwości i grzeszności nie rozpoznaje właściwej istoty usprawiedliwienia. Karl Rahner nie poprzestaje na krytycznym spojrzeniu, ale stara się ją tak zinterpretować, aby mogła być zaakceptowana w łonie katolicyzmu. Jest to możliwe, jeśli ludzka podmiotowość nie stanie się podstawą usprawiedliwienia, a stroną przyjmującą łaskę usprawiedliwienia, która będzie wzrastać w procesie uświęcenia ${ }^{37}$.

36 Por. Dodatek do Wspólnego Oficjalnego Oświadczenia Światowej Federacji Luterańskiej i Kościoła katolickiego, 2B, „Studia i Dokumenty Ekumeniczne” nr 2 (1999), s. 138; Quellen zur Gemeinsamen Erklärung zur Rechtfertigungslehre, „Texten der Vereinigten Evangelisch-Lutherischen Kirche Deutschlands" Juni 1999, nr 87, s. 11; V. Mshanga, Simul iustus et peccator, dz. cyt., s. 587.

37 Por. K. Rahner, Gerechter und Sünder zugleich, [w:] K. Rahner, Schriften zur Theologie, Einsiedeln 1983, t. 6, s. 265-270; A. Morimoto, Jonathan Edwards and the Catholic vision of salvation, Pennsylvania 1995, s. 160-163. 
Rahner zgadza się co to luterańskiego przekonania, że grzech niejako włada człowiekiem, ale zauważa, iż luteranie nie dokonują rozróżnienia między grzechami lekkimi i ciężkimi. W tej kwestii rodzi się pytanie, jak można pogodzić stan łaski, w perspektywie katolickiej, z ciężkimi grzechami człowieka? Recepcja, według Rahnera, powinna iść po linii pojęcia łaski. Człowiek sam z siebie jest tylko grzesznikiem i gdyby pokładał ufność we własne siły, to na pewno odwróciłby się od Boga. Tak więc niezbywalna jest zbawiająca łaska, która przychodzi do człowieka, ogarnia go i uwalnia. Wobec tej łaski jest on zawsze grzesznikiem. Na tym etapie refleksji niemiecki teolog dopuszcza możliwość, że katolicy mogą wraz z luteranami powiedzieć, że człowiek jest jednocześnie grzeszny i usprawiedliwiony. Zastrzega jednak, że sformułowanie simul (jednocześnie) nie oznacza jednoczesności początku i końca, lecz jest jednoczesnością w napięciu między obydwoma wymiarami ${ }^{38}$. Można powiedzieć, że głównym punktem niezgody w Rahnerowskiej koncepcji pozostaje nauka o łasce, opierająca się na nadal dzielących aspektach teologii dogmatycznej, a szczególnie na eklezjologii, sakramentologii i kwestii synergizmu ${ }^{39}$.

\section{Nowa perspektywa zrozumienia idei simul iustus et peccator}

Nauczanie Lutra, że usprawiedliwiony jest jednocześnie sprawiedliwy i grzeszny, w świetle badań egzegetów biblijnych i teologów nie ma prawie żadnych podstaw biblijnych. W latach sześćdziesiątych ubiegłego wieku Komisja Teologiczna Światowej Federacji Luterańskiej w Helsinkach wyraziła przekonanie, że Nowy Testament nie zna pojęcia simul iustus et peccator. Chrześcijanin jest święty i już dłużej nie jest grzesznikiem. Prawdą jest, że św. Paweł i św. Jan zaprzeczają, że ochrzczony jest wolny od grzechu. Natomiast świadomość grzechu wzywająca do stałej

38 Por. K. Rahner, Gerechter und Sünder zugleich, dz. cyt., s. 274-275; S. Duffy, Experience of grace, [w:] The Cambridge companion to Karl Rahner, ed. D. Marmion, Cambridge 2005, s. 43-64.

${ }_{39}$ Por. K. Rahner, Grundkurs des Glaubens - Vierter Gang. Der Mensch als das Ereignis der freien, vergebenden Selbstmitteliung Gottes, Freiburg 1985, s. 122-125; F. Nüssel, Grund zur Aufgeschlossenheit - Denkanstöße Karl Rahners für die gegenwärtige evangelische Theologie, „Materialdienst des Konfessionskundlichen Instituts Bensheim" 2 (2004), s. 23-29. 
postawy nawrócenia jest obca Nowemu Testamentowi. Samo zaś badanie owego nauczania jest stopniową indywidualizacją i psychologizacją doktryny o usprawiedliwieniu ${ }^{40}$. Dla luterańskiej komisji idea kreowana przez ojca reformacji jest abstrakcją z dialektyki św. Pawła między ciałem i duchem. Jednakże jest ona świadoma, że istnieje różnica między grzechem usprawiedliwionego a grzechem nieochrzczonej osoby. Dlatego chrześcijanin nie powinien być traktowany jako jednocześnie ocalony i potępiony ${ }^{41}$.

W tym względzie najlepszym rozwiązaniem jest postrzeganie interesującej nas kontrowersji jako teologicznej opinii, co powinno zniwelować główną przeszkodę na drodze do widzialnej jedności Kościołów. Można wskazać punkty zbieżne między luterańską koncepcją i wizją katolików dotyczące nauczania, że wierzący jest grzesznikiem. Luteranie w pierwszej kolejności wskazują, że sprawiedliwy jest grzesznikiem tak daleko, jak pożądliwość, która obiera nową formę w postaci panowania grzechu lub pozostającego w człowieku grzechu poskromionego (peccatum regnatum). Po drugie, usprawiedliwiony pozostaje równocześnie świętym i grzesznikiem w takim stopniu, w jakim kontynuuje wybór grzechu w całym swoim życiu. Z kolei katolicy opowiadający się za tym, że wierzący jest cały sprawiedliwy, chociaż grzeszy, nie identyfikują ontologicznie grzesznika z grzechem. Oznacza to, że usprawiedliwiony jest simul iustus et peccator tak bardzo, jak ochrzczeni, mający skłonność do grzechu, nawet powszedniego. Księga Przysłów potwierdza, że nawet święty grzeszy siedem razy dziennie, to jednak podnosi się ponownie (Prz 24, 16). Pojawiające się grzechy u wierzącego mają swoje źródło w pozostającej po chrzcie pożądliwości, która choć jest w opozycji do Boga, nie oddziela człowieka od Stwórcy. Na przeciwległych biegunach są dwie koncepcje. Jedna, w której pożądliwość obecna w ochrzczonym jest rzeczywiście grzechem, ale nie oddziela go od Chrystusa tak długo, jak on sam nie pozwala pano-

40 Por. Justification today: studies and reports, „Lutheran World Supplement” no. 1 (1965), s. 13-75; J. Fitzmyer, According to Paul: studies in the theology of the Apostle, New York 1993, s. $115-121$.

${ }^{41}$ Por. M. Brinkman, Justification in ecumenical dialogue: central aspects of Christian soteriology in debate, Utrecht 1996, s. 178-180; E. Jüngel, Justification: the heart of the Christian faith, London 2006, s. 215. 
wać grzechowi, oraz druga, w której pożądliwość, ponieważ nie oddziela ochrzczonego od Chrystusa, jest tylko skłonnością do grzechu i staje się dopiero naprawdę grzechem, kiedy człowiek wyraża na to zgodę. Można powiedzieć, że przy takim rozumieniu żaden z powyższych poglądów teologicznych nie uzasadnia wzajemnego potępienia pod zarzutem propagowania herezji ${ }^{42}$.

Obie wspólnoty eklezjalne wyrażają swoje własne spostrzeżenia teologiczne dotyczące wpływu bezwarunkowego daru Bożego zbawienia. Płaszczyzną porozumienia, jak zostało zasygnalizowane wyżej, może być rozumienie problematycznej kontrowersji w kategoriach theological statement. Skłania do tego fakt, że w związku ze Wspólną deklaracją nauka grzeszności usprawiedliwionego nadal stanowi przeszkodę dla widzialnej jedności między luteranami i katolikami. Z jednej strony w podpisanym dokumencie zostało oficjalnie potwierdzone, że potępienia doby reformacji nie mogą być już więcej uważane za właściwe, z drugiej strony Kościół katolicki nadal piętnuje stanowisko luterańskie w tej kwestii. W Odpowiedzi Kościoła katolickiego na Wspólną deklarację wyraźnie wyjaśniono, że pojęcie usprawiedliwionego jako grzesznika, jak przedstawiają to pierwsze zdania nr. 29 Wspólnej deklaracji, jest po prostu nie do przyjęcia i wypowiedź ta wydaje się być nie do pogodzenia z odnową i uświęceniem człowieka wewnętrznego, o którym jest mowa w dekrecie o usprawiedliwieniu Soboru Trydenckiego ${ }^{43}$. Z kolei określenie „sprzeciwianie się Bogu” (Gottwidrigkeit), o którym jest mowa w nr. 28-30, jest różnie rozumiane przez katolików i luteranów, stając się faktycznie pojęciem wieloznacznym. W taki sam sposób zdanie zamieszczone pod nr. 22: „Bóg nie zalicza mu grzechu, a Duch Święty wzbudza w nim czystą miłość” - jest dla katolików nie dość jednoznaczne, ponieważ nie dochodzi tutaj wyraźnie do głosu wewnętrzna przemiana człowieka. Z wszystkich tych powodów trudności sprawia wypowiedź, jakoby nauka dotycząca simul iustus et peccator w aktualnej wersji, przedłożonej we Wspólnej deklaracji, nie pod-

42 Por. T. Schneider, G. Wenz, Gerecht und Sünder zugleich?, vol. 11, Freiburg 2001, s. 439; V. Mshanga, Simul iustus et peccator, dz. cyt., s. 587-598.

43 Por. Sobór Trydencki, Dekret o usprawiedliwieniu, rozdz. 8, dz. cyt., s. 298; Sobór Trydencki, Kanony o usprawiedliwieniu, kan. 11, [w:] Dokumenty Soborów Powszechnych..., dz. cyt., s. 312; W. Medwid, Usprawiedliwienie w dialogu katolicko-luterańskim, dz. cyt., s. 114-117, 183. 
legała już potępieniom dekretów trydenckich o grzechu pierworodnym i usprawiedliwieniu ${ }^{44}$.

Przy takim stanie rzeczy trudno sobie wyobrazić, w jaki sposób oba Kościoły mogą osiągnąć trwałą widzialną jedność, gdy przedstawione powyżej nauczanie każdej ze wspólnot pozostaje nadal nierozwiązane, co najmniej w sposób zróżnicowany. Metoda opinii teologicznej stwarza podstawy, aby interesującą nas kontrowersję rozważyć w ramach różnie interpretowanej przez dwie tradycje eklezjalne opinii teologicznej. Ujęcie problemu w takich kategoriach może niwelować podział Kościołów. Należy zaznaczyć, iż powyższa formuła pozostaje kwestią otwartą. Praktycznie rzecz biorąc dla luteranów, interpretując ją według relacyjnej ontologii, usprawiedliwiony uważany jest za całkowicie sprawiedliwego, a interpretując według ontologii substancji - jest całkowicie grzesznikiem. Mimo że pożądliwość jest w przeciwieństwie do Boga, to nie prowadzi do potępienia. Z kolei dla katolików usprawiedliwiony, odradzający się w łasce sakramentu chrztu jest nowym stworzeniem, ale potem musi nieustannie walczyć z grzesznymi skłonnościami w sobie. Jest on grzesznikiem tak długo, jak nakłoniony przez pożądliwość w dalszym ciągu popełnia grzechy. Warto podkreślić, iż Kościół katolicki nie zaprzecza temu, że wierzący po chrzcie nadal grzeszą ${ }^{45}$.

Przez taki pryzmat świadomości ojcowie soboru watykańskiego II w konstytucji dogmatycznej o Kościele Lumen gentium stwierdzają (nie identyfikując ontologicznie ludzkości z grzechem), że wierzący są simul iustus et peccator. W dokumencie czytamy:

Chrystus posłany został przez Ojca, ,aby głosić ewangelię ubogim... aby uzdrawiać skruszonych w sercu” (Łk 4,18), ,aby szukaći zbawiać, co było zginęło” (Łk 19, 10), podobnie i Kościół darzy miłością wszystkich dotkniętych słabością ludzką, co więcej, w ubogich i cierpiących odnajduje wizerunek swego ubogiego i cierpiącego Zbawiciela, im stara się ulżyć w niedoli i w nich usiłuje służyć Chrystusowi. A podczas gdy Chrystus, „święty, niewinny, niepokalany” (Hbr 7, 26), nie znał grzechu (2 Kor 5, 21), lecz przyszedł dla przebłagania jedynie za grzechy ludu (por.

${ }_{44}$ Por. Odpowiedź Kościoła katolickiego na Wspólna deklarację, „Studia i Dokumenty Ekumeniczne” 2 (1998), s. 75; Response of the Catholic Church to the Joint declaration, „Information Service. The Pontifical Council for Promoting Christian Unity” no. 98 (1998), s. 94; R. Hermann, Luthers These „Gerecht und Sünder zugleich”, Darmstadt 1960, s. 48-77.

45 Por. M. Brinkman, Justification in ecumenical dialogue: central aspects of Christian soteriology in debate, dz. cyt., s. 22. 
Hbr 2,17), Kościół obejmujący w łonie swoim grzeszników, święty i zarazem ciągle potrzebujący oczyszczenia, podejmuje ustawicznie pokutę i odnowienie swoje ${ }^{46}$.

Również w dekrecie o ekumenizmie (Unitatis redintegratio) wspomnianego soboru można dostrzec ideę jednoczesnej sprawiedliwości i grzeszności wierzącego: „Lud ten wprawdzie podczas swojej ziemskiej wędrówki nie przestaje podlegać grzechowi w członkach swoich, ale mimo to wzrasta w Chrystusie, a Bóg wiedzie go łaskawie wedle swoich tajemnych planów aż do radosnego zdobycia całej pełni wiecznej chwały w niebieskim Jeruzalem" ${ }^{47}$. Nie będzie nadużyciem stwierdzenie, że Vaticanum II wyraził to, co można by nazwać katolicką nauką simul iustus et peccator ${ }^{48}$.

\section{Podsumowanie}

Dojście, w jaki sposób podejść do zagadnienia jednoczesnej sprawiedliwości i grzeszności usprawiedliwionego, aby nie było ono przeszkodą na drodze do jedności obu Kościołów, wymagało zastosowania metody, która dopuszczałaby opinie obu Kościołów bez wzajemnego wykluczania się. Nauka o grzeszności wierzącego nie miała na celu tylko odrzucenia własnej sprawiedliwości, ale także zachęcenie skrupulatnego i zrozpaczonego sumienia do ufności w Boże miłosierdzie. Trzeba nieustannie robić krok naprzód w interpretacji tego problemu, aby przezwyciężyć teologiczno-ekumeniczny impas.

Począwszy od św. Augustyna i jego wizji grzechu pierworodnego, łaski i pożądliwości, przez Marcina Lutra i jego koncepcję grzechu pozostającego w człowieku po chrzcie, aż po dwudziestowieczny dialog katolicko-luterański z jego próbami osiągnięcia konsensusu oraz Karla Rahnera i jego refleksje co do działania łaski, trzeba stwierdzić, że istnieją trzy stopnie porozumienia w naturze człowieka będącego usprawiedliwionym. Po pierwsze, jest on naprawdę i rzeczywiście odnowiony i uświęcony i zosta-

\footnotetext{
46 Sobór Watykański II, konst. Lumen gentium, 8.

47 Sobór Watykański II, dekret Unitatis redintegratio, 3.

48 Por. A. Grillmeier, The people of God, [w:] Commentary on the documents of the Second Vatican Council II, ed. H. Vorgrimler, London 1967, s. 153-175; R. Hermann, Luthers These „Gerecht und Sünder zugleich", dz. cyt., s. 193-217; V. Mshanga, Simul iustus et peccator, dz. cyt., s. 588-589.
} 
ły mu odpuszczone grzechy. Po drugie, w usprawiedliwionym pozostaje pożądliwość i skłonność do grzechu (concupiscentia). Po trzecie, musi się on przez całe życie zmagać z tymi skłonnościami. Główną różnicę między dwoma Kościołami stanowi fakt, że luteranie wyobrażają sobie ludzi jako grzesznych od urodzenia aż do śmierci, z kolei katolicy postrzegają ludzi jako potencjalnych grzeszników po chrzcie. Radykalny sposób nauczania Lutra w sprawie grzeszności usprawiedliwionego wynikał zapewne z polemicznego charakteru środowiska doby szesnastowiecznej reformacji. Taki stan rzeczy zainicjował konieczność zrozumienia kontrowersji simul iustus et peccator jako opinii teologicznej. Jakkolwiek podejmowanie finalnych twierdzeń odnośnie do charakteru zbawczych działań Bożych wobec człowieka jest w dużej mierze ograniczone. Stąd dla Kościoła katolickiego rodzi się świadomość refleksji nad usprawiedliwionym jako grzesznikiem przez wzgląd na popełnione po chrzcie grzechy. Natomiast dla luteranów to świadomość usprawiedliwionego jako grzesznika przed chrztem, w jego trakcie i po nim. Według mnie oba Kościoły pomimo zróżnicowanych interpretacji grzechu mają możliwość zrozumienia wierzącego jako sprawiedliwego i grzesznego zarazem. Jest to również szansa zbliżenia teologicznego w tej kwestii, choć wymaga to jeszcze wielu studiów, analiz i rozmów mających na celu zniwelowanie głównej dzielącej przeszkody. Trafne w tej sytuacji mogą być słowa papieża Jana XXIII, który mówił, że trzeba zaprowadzać w potrzebie - jedność, w rzeczach wątpliwych - swobodę, we wszystkim - miłośćc ${ }^{49}$.

49 Por. Ioannes XXIII, Ad Petri Cathedram, 72, „Acta Apostolicae Sedis” 51 (1959), s. 515; V. Mshanga, Simul iustus et peccator, dz. cyt., s. 589-590. 


\section{Summary}

\section{Cross the Threshold of Simultaneous Righteousness and Sinfulness of the Believer}

The article concerns the attempt to present the issue of simultaneous righteousness and sinfulness of the believer (simul iustus et peccator) in that light, in order to effectively seek to break the deadlock in the ecumenical issue and see in the long term the apparent unity of the two Christian communities, while not ignoring both traditions. It is an attempt to answer the question how the Catholics and Lutherans should approach the heart of the matter, and how to teach in this regard, to compensate for the ongoing disparity and division of Churches. For this reason, the source of complication lies in different understanding of the concept of sin by the two churches, the analysis proceeds in terms of desires and using the method of theological statement. The problem is shown in the context of the historical and theological ranging from St. Augustine, a precursor to the study, through Martin Luther, the main defender and propagator of this idea, also the documents of the Council of Trent, until the Catholic-Lutheran dialogue in the second half of the twentieth century. Interesting comments on this topic can be found in Karl Rahner, in the documents of the Second Vatican Council, especially in Joint Declaration on the Doctrine of Justification signed by Catholics and Lutherans, especially in terms of justified sinfulness.

Keywords: simultaneously righteous and sinful (simul iustus et peccator), concupiscence, Martin Luther, Saint Augustine, ecumenical dialogue, the concept of sin, Joint Declaration on Justification.

\section{Przekroczyć próg jednoczesnej sprawiedliwości i grzeszności wierzącego}

Artykuł dotyczy próby przedstawienia problemu jednoczesnej sprawiedliwości i grzeszności człowieka wierzącego (simul iustus et peccator) w takim świetle, aby skutecznie dążyć do przełamania ekumenicznego impasu w tej materii i widzieć w perspektywie czasu zarysowującą się jedność obu wspólnot chrześcijańskich, nie pomijając obu tradycji. Jest to próba odpowiedzi, w jaki sposób katolicy i luteranie powinni podejść do istoty zagadnienia oraz do nauczania w tym względzie. Poniewaź źródłem komplikacji jest różne rozumienie pojęcia grzechu, analiza przebiega pod kątem pożądliwości oraz przy zastosowaniu metody opinii teologicznej. Problem jest przedstawiony w kontekście historycznym i teologicznym, począwszy od św. Augustyna, przez Marcina Lutra, głównego obrońcę i propagatora tej idei, a także w dokumentach Soboru Trydenckiego, aż do katolicko-luterańskiego dialogu w drugiej połowie XX wieku. Ciekawe komentarze na ten temat można znaleźć u Karla Rahnera, w dokumentach Soboru Watykańskiego II, a zwłaszcza we Wspólnej deklaracji w sprawie 
nauki o usprawiedliwieniu podpisanej przez katolików i ewangelików, szczególnie pod względem usprawiedliwienia grzesznika.

Słowa kluczowe: jednocześnie sprawiedliwy i grzeszny (simul iustus et peccator), pożądliwość, Marcin Luter, św. Augustyn, dialog ekumeniczny, pojęcie grzechu, Wspólna deklaracja o usprawiedliwieniu

\section{Bibliografia}

Althaus P., The theology of Martin Luther, Philadelphia 1970.

Augustyn, Do Symplicjana o różnych problemach, [w:] De sermone Domini in monte, tłum. F. Ryznar, J. Sulowski, Warszawa 1989, s. 112-203 (Pisma Starochrześcijańskich Pisarzy, 48).

Augustyn, Państwo Boże, przeł. W. Kubicki, Kęty 1998.

Balthasar H., Skizzen zur Theologie, t. 2, Freiburg 1971.

Bayer O., Martin Luther's theology: a contemporary interpretation, Grand Rapids 2008.

Bonaiuti E., La Piana G., The genesis of St. Augustine's idea of original sin, „Harvard Theological Review" 10/2 (1917), s. 159-175.

Brinkman M., Justification in ecumenical dialogue: central aspects of Christian soteriology in debate, Utrecht 1996.

Couenhoven J., St. Augustine's doctrine of original sin, „Augustinian Studies” 36/2 (2005), s. 359-396.

Dodatek do Wspólnego Oficjalnego Oświadczenia Światowej Federacji Luterańskiej i Kościoła katolickiego, „Studia i Dokumenty Ekumeniczne” 2 (1999), s. 138-140.

Dorman T., Justification as healing, "Quodlibet Journal of Christian Theology and Philosophy" 2 (2000), s. 1-12.

Duffy S., Experience of grace, [w:] The Cambridge companion to Karl Rahner, ed. D. Marmion, Cambridge 2005, s. 43-64.

Fitzmyer J., According to Paul: studies in the theology of the Apostle, New York 1993.

Grillmeier A., The people of God, [w:] Commentary on the documents of the Second Vatican Council II, ed. H. Vorgrimler, London 1967, s. 153-175.

Hermann R., Luthers These „Gerecht und Sünder zugleich”, Darmstadt 1960.

Jüngel E., Das Evangelium von der Rechtfertigung des Gottlosen als Zentrum des christlichen Glaubens, Tübingen 1998.

Jüngel E., Justification: the heart of the Christian faith, London 2006.

Justification by faith (Common Statement), [w:] Justification by faith. Lutherans and Catholics in Dialogue VII, eds. H. G. Anderson, T. A. Murphy, J. A. Burgess, Minneapolis 1985 , s. $13-74$.

Justification today:studies and reports, ,Lutheran World Supplement” 1 (1965), s. 13-75.

Karski K., Protestanci i ekumenizm. Wkład spadkobierców Reformacji w dzieło jedności, Warszawa 2001.

Kawerau G., Latomus, Jacobus, [w:] The New Schaff-Herzog encyclopedia of religious knowledge, London-New York 1910, vol. 6, s. 420-422. 
Lamberigts M., A critical evaluation of critiques of Augustine's view of sexuality, [w:] In Augustine and his critics, eds. R. Dodaro, G. Lawless, London 2000, s. 176-197.

Lane A., Justification by faith in Catholic-Protestant dialogue, New York 2006.

Lazareth W., Christians in society: Luther, the Bible, and social ethics, Minneapolis 2001.

Lehrverurteilungen - kirchentrennend?, t. 1: Rechtfertigung, Sakramente und Amt im Zeitalter der Reformation und heute, hrsg. von K. Lehmann, W. Pannenberg, FreiburgGöttingen 1986.

Lindbeck G., A question of compatibility: a Lutheran reflects on Trent, [w:] Justification by faith. Lutherans and Catholics in Dialogue VII, eds. H. G. Anderson, T. A. Murphy, J. A. Burgess, Minneapolis 1985, s. 230-240.

Lipniak J., Ekumeniczne usprawiedliwienie podzielonych grzeszników, Świdnica 2006.

Loux M., Metaphysics: a contemporary introduction, Oxford 2002.

Luther A., Against Latomus, [w:] Luther's works, eds. J. Pelikan, H. Oswald, H. Lehmann, vol. 32, Philadelphia 1999.

Luther M., De libertate christiana, [w:] Martin Luthers Werke. Weimarer Ausgabe, vol. 7, Böhlaus Nachfolger 2003, s. 49-73.

Luther M., Lectures on Romans: glosses and scholia, Philadelphia 1972 (Luther's Works, 25).

Luther M., The Disputation concerningjustification (1536), Philadelphia 1960 (Luther's Works, 34).

Luther M., The private mass and the consecration of the priests, Philadelphia 1971 (Luther's Works, 38).

Lutheran Church Missouri Synod, The Joint declaration on the doctrine of justification in confessional Lutheran perspective, "Journal of Evangelical Theological Society" 3 (1999), s. 15-19.

McBrien R., Catholicism, Washington 1996.

Medwid W., Usprawiedliwienie w dialogu katolicko-luterańskim, Kraków 2010.

Mey P., A call to conversion, [w:] Rethinking ecumenism, ed. F. Bakker, Meinema-Zoetermeer 2004, s. 211-228.

Morimoto A., Jonathan Edwards and the Catholic vision of salvation, Pennsylvania 1995.

Mshanga V., Simul iustus et peccator, „Journal of Ecumenical Studies” 45/4 (2010), s. 578-590.

Mullet M., Martin Luther, Oxford 2004.

Napiórkowski A., Bogactwo łaski a nędza grzesznika, Kraków 2000.

Nüssel F., Grund zur Aufgeschlossenheit - Denkanstöße Karl Rahners für die gegenwärtige evangelische Theologie, „Materialdienst des Konfessionskundlichen Instituts Bensheim" 2/2004, s. 23-29.

Odpowiedź Kościoła katolickiego na Wspólna deklarację, „Studia i Dokumenty Ekumeniczne" 2 (1998), s. 74-78. Tekst angielski: Response of the Catholic Church to the Joint declaration, „Information Service. The Pontifical Council for Promoting Christian Unity" 98 (1998), s. 93-95. 
Ökumenischer Arbeitskreis Evangelischer und Katholischer Theologen, Lehrverurteilungen-Kirchentrennend? Materialien zur Lehre von den Sakramenten und vom Kirchelichen, eds. K. Lehmann, W. Pannenberg, vol. 1-4, Freiburg-Göttingen 1986.

Olson R., The story of Christian theology, Westmont 1999.

Pannenberg W., Die Gemeinsame Erklärung zur Rechtfertigung aus römisch-katholischer Sicht, [w:] Zur Zukunft der Ökumene. Die „Gemeinsame Erklärung zur Rechtfertigungslehre”, hrsg. B. Hilberath, W. Pannenberg, Regensburg 1999, s. 79-99.

Pesch O. H., Die Theologie der Rechtfertigung bei Martin Luther und Thomas von Aquin, Mainz 1985.

Quellen zur Gemeinsamen Erklärung zur Rechtfertigungslehre, [w:] Texten der Vereinigten Evangelisch-Lutherischen Kirche Deutschlands, Juni 1999, s. 11.

Rahner K., Grundkurs des Glaubens - Vierter Gang. Der Mensch als das Ereignis der freien, vergebenden Selbstmitteliung Gottes, Freiburg 1985.

Schneider T., Wenz G., Gerecht und Sünder zugleich?, vol. 11, Freiburg 2001.

Sobór Trydencki, Dekret o grzechu pierworodnym, [w:] Dokumenty Soborów Powszechnych: tekst łaciński i polski, t. 4: (1511-1870) Lateran IV, Trydent, Watykan I, układ i oprac. A. Baron, H. Pietras, tłum. A. Baron i in., Kraków 2004, s. 234-240.

Sobór Trydencki, Dekret o usprawiedliwieniu, [w:] Dokumenty Soborów Powszechnych: tekst łaciński i polski, t. 4: (1511-1870) Lateran IV, Trydent, Watykan I, układ i oprac. A. Baron, H. Pietras, tłum. A. Baron i in., Kraków 2004, s. 288-310.

Sobór Watykański II, Dekret o ekumenizmie „Unitatis redintegratio”, [w:] Sobór Watykański II. Konstytucje. Dekrety. Deklaracje, Poznań 2002, s. 203-218.

Sobór Watykański II, Konstytucja dogmatyczna o Kościele „Lumen gentium”, [w:] Sobór Watykański II. Konstytucje. Dekrety. Deklaracje, Poznań 2002, s.105-170.

Stump E., Kretzmann N., The Cambridge companion to Augustine, Cambridge 2001.

Trueman C., Simul Peccator et Justus: Martin Luther and justification, [w:] Justification in perspective: Historical developments and contemporary challenges, ed. B. McCormack, Grand Rapids-Edinburgh 2006, s. 73-90.

Truemper D., Introduction to the Joint declaration on the doctrine of justification, [w:] Rereading Paul together: Protestant and Catholic perspectives on justification, ed. D. Aune, Grand Rapids 2006, s. 28-40.

Wagner H., Dogmatyka, przekł. J. Zychowicz, Kraków 2007.

Wildman W., An introduction to relational ontology, [w:] The Trinity and an entangled world: relationality in physical science and theology, eds. J. Polkinghorne, J. Zizioulas, Grand Rapids 2010, s. 55-73.

Wspólna deklaracja w sprawie nauki o usprawiedliwieniu (1997). Projekt ostateczny, „Studia i Dokumenty Ekumeniczne" 2 (1997), s. 67-79. Tekst oryginalny: Gemeinsame Erklärung zur Rechtfertigungslehre, [w:] Gemeinsame Erklärung zur Rechtfertigungslehre. Ein Kommentar für Ökumenische Forschung, Straßburg 1997, s. 55-77. 